Simo Mikkonen, Giles Scott-Smith, Jari Parkkinen (Eds.)

Entangled East and West 


\section{Rethinking the Cold War}

Edited by

Kirsten Bönker and Jane Curry

\section{Volume 4}




\section{Entangled East and West}

Cultural Diplomacy and Artistic Interaction during the Cold War

Edited by

Simo Mikkonen, Giles Scott-Smith, Jari Parkkinen 
ISBN 978-3-11-057050-2

e-ISBN (PDF) 978-3-11-057316-9

e-ISBN (EPUB) 978-3-11-057060-1

Library of Congress Control Number: 2018958372

Bibliographic information published by the Deutsche Nationalbibliothek

The Deutsche Nationalbibliothek lists this publication in the Deutsche Nationalbibliografie; detailed bibliographic data are available on the Internet at http://dnb.dnb.de.

(C) 2019 Walter de Gruyter GmbH, Berlin/Boston

Cover image: Soviet cultural event in Messuhalli, Helsinki 23.2.1945. Photo by Väinö Kannisto, Helsinki city museum, N153628.

Printing and binding: CPI books GmbH, Leck

www.degruyter.com 